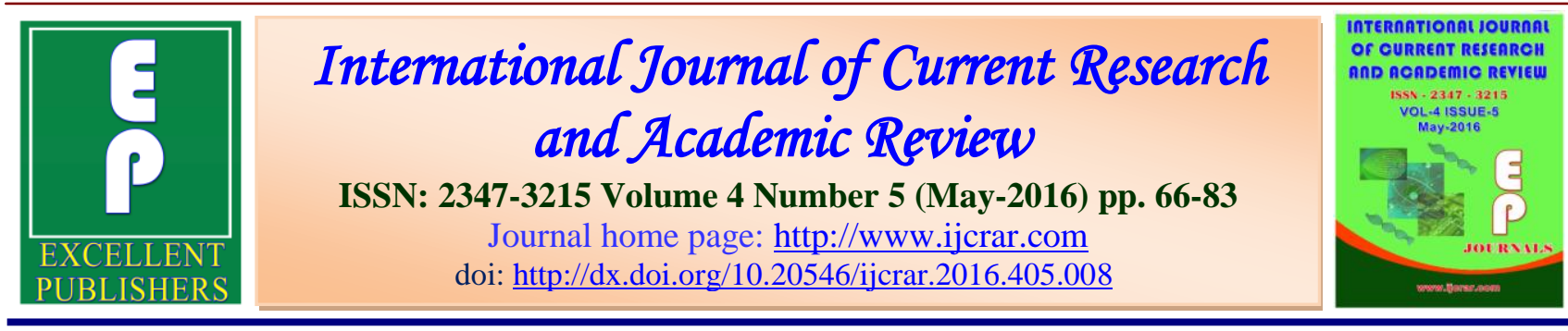

\title{
A Reexamination of COMESA's Aggregate Import Demand Function: Multivariate Cointegration Approach
}

\author{
Clive Mairura ${ }^{1}$, Mark Korir ${ }^{2}$ and T. Anthoney Swamy ${ }^{3 *}$
}

${ }^{1}$ Department of Agricultural Economics and Agribusiness Management, Faculty of Agriculture, Kisii University, P.O Box 408-40200, Kisii, Kenya.

${ }^{2}$ Department of Economics, School of Business and Economics, MoiUniversity, P.O Box 3900-30100, Eldoret, Kenya.

${ }^{3}$ Department of Chemistry, School of Science and Technology, University of Eastern Africa, Baraton, P.O. Box 2500, Eldoret, Kenya.

*Corresponding author

KEYWORDS

Aggregate Import

Demand,

Multivariate

Cointegration,

Error Correction

Mechanism,

COMESA.
$A B S T R A C T$

This study reexamines the behaviour of aggregate import demand function for COMESA using the Johansen Juselius multivariate cointegration approach and error correction mechanism on the annual data for the period 1970 to 2006. Empirical evidence show that aggregate imports, gross domestic product, unit value of imports, prices of domestically produced goods, foreign exchange reserves and the dummy variable to capture the effect of import liberalization are cointegrated. There is a long run equilibrium relationship among variables and the stability tests indicate that the aggregate import demand function remains stable over the sample period and the estimated results are appropriate for policy implication. The estimation of an error correction mechanism enables the separation of the short-run and long-run elements of this relationship. Results show that aggregate import demand is largely explained by real GDP, foreign exchange reserves, prices of domestically produced goods but less sensitive to import prices.

\section{Introduction}

Over the past four decades, a vast amount of research has been devoted to studying the aggregate demand for imports in both developed (Murray and Ginman (1976), Khan and Ross (1977), Boylan etal (1980), Warmer and Kreinin (1983)) and less developed countries (LCD) (Khan (1974,
Sarmad (1988, 1889), Moran (1989), Shilpi (1990), Emran and Shilpi(1996)) with the income and price elasticities of the demand for imports being the most popular and important empirical estimates used in international economics. Deriving such estimates is not only is for academic 
reasons, but it has more implications regarding to the management of the trade balance or in correcting COMESA's trade deficits. Other related studies on many multi-country studies have been done including Bahmani-Osekooe (1998) for six less developed countries and Sinha (2001) for five Asian countries.

Nevertheless, there have been setbacks with some previous studies because of using ordinary least squares method (OLS) to estimate the import demand function with assumptions that there exists an underlying equilibrium relationship between the quantity/volume of imports and regressors in the model. Granger and Newbold (1974) showed an unsatisfied stationary assumption as a result of using OLS method that lead to spurious regression and unreliable statistical inferences. Furthermore, Goldstein and Khan (1985) suggested that trade relationship are subject to either gradual or sudden changes over time. They debated that gradual changes are due to the process of economic development or even as a result of changes in government policies whereas sudden changes are due to fluctuation exchange rates that alter the basic demand or supply relationship.

The major objective of this study is to reestimate the aggregate import demand function for COMESA on the basis of annual data for the period 1970 to 2006 . The first hypothesis is to test the existence of a cointegrated relationship between the quantity of aggregate import and its major determinants using a multivariate cointegration approach developed by Johansen (1988, 1991) and JohansenJuselius (1990, 1992 and 1994). Cointegration approach as the literature has it, increases the reliability of econometric modeling by taking into account on nonstationary data (Hickling, 2006 and
Johansen, 1988). Secondly, estimate Error Correction Model (ECM) to integrate the dynamics of the short - run (changes) with long run (levels) adjustment process. Thirdly, determine the effects of trade reforms particularly the liberalization policy since 1992 on the aggregate import demand behaviour of COMESA. Finally, this paper determines the stability of the aggregate import model used.

\section{Methodology and Data Sources}

The analysis of cointegration starts with the determination of the univariate properties of the time series. The implementation of the cointegration method necessities the prior check for non-stationarity of data. In time series literature, unit root tests are widely used for testing stationary (non-stationary) in economic data. The standard statistical properties of OLS hold only when the time series variables involved are stationary. A time series is said to be stationary if its mean, variance, and autocovariance are independent of time. The ADF, PP and DF-GLS unit root tests were conducted on both in levels and firstdifferences for all the variables under study.

The presence of unit root in the time series data generates unreliable results regarding the hypothesis testing. Therefore, before carrying out hypothesis testing, the nonstationary data need to be differenced until stationarity has emerged. The null hypothesis is that the variable contains a unit root, and the alternative is that the variable was generated by a stationary process. Moreover the concept of cointegration requires that the set of variables should be integrated of the same order and their linear combination must be stationary. If the series do not follow the same order of integration then there can be no meaningful relationship among them. If series are integrated of the 
same order, we can proceed to the cointegration test.

A test for cointegration analysis means looking for stable long-run equilibrium relationships among non-stationary economic variables. If the results indicate that the absence of cointegrating vectors between the variables, it means that there does not exist a long-run stable relationship between them. If cointegration exists, then it can be presumed that a one -way or twoway Granger causality exists in at least the stationery series. If variables are found to be non-stationary at levels and they are determined to be stationary in their first differences, they are said to be integrated of order one (1). They are many approaches to test cointegration. This include the Engle and Granger (1987) two step procedure; and the Johansen (1988) and Johansen and Juselius (1990) procedure. To test for cointegration among macro-economic variables, we adopt the procedure developed by Johansen (1988) and Johansen and Juselius (1990) since this specific procedure is claimed to be superior to the regression analysis based Engle Granger (EG) procedure. This is because in EGprocedure, the estimation of the long-run equilibrium requires that all variables be treated as regressors and run a subsidiary or auxiliary regressions. You treat each variable in the model as a regressand and regress against the remaining variables. However in practice, it is possible to find that one regression indicates the variables are cointegrated, whereas reversing the order indicates no cointegration. This is very undesirable feature of the procedure since the test for cointegration should be invariant to the choice of the variable selected for normalization.

The $\mathrm{JJ}$ procedure is superior because it does not rely on an arbitrary normalization. The
Engle-Granger procedure is inferior to $\mathrm{JJ}$ procedure because it does not account for the possibility of multiple cointegrating relationships and hence all possible dynamic interactions that could exist between two or more time series. If a multiple cointegrating vector exists, the use of Engle Granger procedure may produce a complex linear combination of all the distinct cointegrating vectors that cannot be sensibly interpreted. In contrast, JJ (1990) procedure provides a unified framework for the estimation and testing of cointegrating relations in the context of VAR error correction methods. It allows for tracing more than one cointegrating vector in the data by calculating the maximum likelihood estimates. Furthermore, procedure fully captures the underlying time series properties of the data and provides estimates of all the cointegrating vectors that exist within a set of variables. It clearly shows whether the system consists of a unique cointegrating vector or a linear combination of several cointegrating vectors.

Finally, the JJ procedure allows for testing certain restrictions suggested by economic theory, such as sign and size of the coefficient estimates of the variables. Unlike, JJ procedure, the EG two step procedures does not easily accommodate dynamics in the cointegrating analysis. There are concerns about small sample bias in estimates from Engle Granger procedure. Use of standard OLS technique in EG procedure when the variables are nonstationary in their levels, could be inappropriate because the usual $t$ and $F$ tests may give misleading results (Engle and Granger, 1987) and the estimated regression coefficient could be 'spurious' (Granger and Newbold, 1974). In order to avoid the limitations of the OLS technique, as most of the macro economic variables are found to be non-stationary, you take first difference 
of variables (Box and Jenkins, 1970) and use superior procedures. But, this also results in removing out the long run characteristics of the data, thereby making the model capable or explaining only short run effect. However, even if the variables are nonstationary but are integrated in the same order, it is possible to check whether they are co-integrated or not. If variables are cointegrated, then it indicates that the linear combinations or the variables are stable in the long-run.

The most important finding of co-integration analysis is "The Granger Representation theorem," It states that if a set of variables are co-integrated of order one (1), there exists a valid error correction representation of data. Once the variables are found to be co-integrated the 'Granger (1987) representation theorem' should be invoked to construct an error correction model (ECM). Once the variables included in the VAR model are found co-integrated, the next step is to specify and estimate an error correction model (ECM) including the error correction term to investigate the dynamic behaviour of the model. The correspondence between co-integration and error correction model is formulized in the Granger representation theorem (1987). The size of the error correction term indicates the speed of adjustment of any disequilibrium towards a long run equilibrium states.

\section{Model Specification Methodology and Data Sources}

There are several and different econometric methods of modeling demand for imports and exports. The appropriate model depends on different factors: the objectives of what the model is constructed that is whether model is for hypothesis-testing or forecasting; data availability and the level of disaggregation; the type of traded goods (homogeneous or highly differentiated goods); the end use to which the traded commodity is put (final consumption or as a factor input) and the required degree of explanation. For example, the traditional formulation of import demand equation relates the quantity of import demanded to domestic real income and relative prices (ratio of import prices to domestic prices) (Gafar 1988). Economic theory has further suggested three leading theories that explain demand for imports and help to determine the appropriate econometric method to be used in modeling an aggregate import demand function. First is the theory of comparative advantage or theory neoclassic trade theory, second is the perfect substitute's model or Keynesian trade multiplier, and thirdly is the imperfect competition also known as the new trade theory. Out of three leading theories, there are two trade models that have been widely used in the international trade literature: the imperfect substitutes model and the perfect substitutes model. If the trade studies deal with aggregate imports (exports), the two models could be viewed as competitors. If, however, disaggregation is allowed, the two models could be viewed as complements one dealing with trade for differentiated goods, and the other with trade for close - if not - perfect substitutes.

The imperfect substitute's theory/model was employed in this study due to the fact that neither exports nor imports are perfect substitutes for domestic goods. It is to more realistic as compared to the perfect and comparative advantage theory. Just like any other demand model, the standard specification of the aggregate import demand model treats quantity of import demanded as regress and other determinants like gross domestic product, unit value import prices, price of domestically produced goods and foreign exchange reserves as regressors. 
Since COMESA imports are only a relatively small fraction of the total world imports, it may be quite realistic to assume that the world supply of imports to COMESA is perfectly since the rest of the world may be able to increase its supply of exports to this region even without an increase in prices. Infinite import supply elasticity assumption reduces our model to a single equation model of an import demand function. In this model, gross domestic product, import price and prices of domestically produced goods variables are crucial, because the effectiveness of import trade policy is highly dependent upon the size of their elasiticities. Other econometric investigations of import demand postulate that the quantity demand for imports is a function of relative prices and real income (Houthakker and Magee (1969), Leamer and Stern (1970), Murray and Ginman (1976), Goldstein and Khan (1985), Dornbusch (1988) and Carone (1996)).

It has also been hypothesized that quantity of imports in any region is largely dependent upon the availability of international reserve to finance imports. The reserves are basically held to achieve a balance between demand for and supply of foreign currencies, for intervention, and to preserve confidence in the region/country's ability to carry out external transactions. Foreign exchange reserve was therefore considered as one of the regressors in the aggregate import demand model for COMESA.

In the area of international trade the most commonly encountered functional forms for import and export demand relationships are either linear or log-linear formulations (Kreinin (1967), Khan (1974), Magee (1975). Recent studies by Doroodian et al. (1994), Sinha (1997), and Raijal et al. (2000) used the Box and Cox (1964) procedure and showed that $\log -\log$ specifications are more preferable to the linear specification. Since economic theory does not provide a priori criteria for selecting the appropriate functional form, the question of choice then becomes an empirical problem. The logarithm formulation is preferable in modeling import demand function for two main reasons. First, it allows imports to react proportionately to rise and fall in the explanatory variables, Khan (1975). Second, it gives direct estimation of import elasticity. Moreover, the use of the log-linear formulation constrains the prices and income elasticity estimates to be constant over the estimation period while the linear form of the import demand equation implies decreasing price elasticity and an income elasticity tending towards one. Thus the variables used in this study are in natural logarithms.

Accordingly, this study used Mairura model (2015) specified in equation in log-linear form. It is a single log linear structural econometric model with six macroeconomic variables which incorporates real aggregate quantity of imports, foreign exchange reserves, real gross domestic product (GDP), unit value of import prices, prices of domestically produced goods and dummy variable capturing structural changes. The log-linear form is considered most appropriate by various empirical studies. This functional form gives elasticity coefficients directly. Moreover, log linear

form reduces the problem of heteroscedasticity in an empirical analysis.

Therefore, empirical results estimated by this model are appropriate for policy implication. This model is used for determining the existence of long run and short term relationships between the quantity of real aggregate imports and its major determinants and the effect of liberalization policy on import demand 
respectively. It is a consistent and empirically implementable model of aggregate imports for COMESA and other developing nations.

$\ln M_{t}=\xi_{0}+\xi_{1} \ln Y_{t}+\xi_{2} \ln P_{t}^{m}+\xi_{3} \ln P_{t}^{d}+\xi_{4} \ln R_{t}+\omega D+u_{t}$ (1)

Where:-

$\ln M_{t}=$ Natural logarithm of real quantity of aggregate import demanded by COMESA region in the time period $(t)$

$\ln Y_{t}=$ Natural logarithm of real gross domestic product of COMESA region in the time $(t)$

$\ln P_{t}^{m}=$ Natural logarithm of unit value of import prices of COMESA region in the time $(t)$

$\ln P_{t}{ }^{d}=$ Natural logarithm of the price index of domestically produced goods of COMESA region in the time $(t)$

$\ln R_{t}=$ Natural logarithm of foreign exchange reserves of COMESA region in the time $(t)$

$D=$ is a dummy variable to capture the effect of import liberalization with values 0 for 1970-91and 1 for 1992-2006.

The expected sign of the coefficient of the dummy variable does not have any theoretical support. However, if the coefficient is significant statistically, then the trade reform exercise of liberalization since 1992 has a significant effect on the demand for imports depending on the sign. With the adoption of the a Structural Adjustment Program (SAP) which marked a major shift in the trade policies of COMESA, Import liberalization, through easing access to imports, is likely to result in a larger aggregate import demand by the economy.

With the adoption of the a Structural Adjustment Program (SAP) which marked a major shift in the trade policies of COMESA, Import liberalization, through easing access to imports, is likely to result in a larger aggregate import demand by the economy. $u_{t}=$ Stochastic term with its usual classical properties. The stochastic term is assumed to berandomly and normally distributed with constant varianceexpressed as $\mu \sim N\left(0, \sigma_{\mu}^{2}\right)$.

$\xi_{1}, \xi_{2}, \xi_{3}$ and $\xi_{4}$ are the long-run coefficients. The constant term " $\xi_{0}$ " is included because of the fact that there will be some imports even if all other variables are zero. Through $u_{t}$, the residual term, it has been shown that imports are also affected by other variables which are not included in the model.

The underlying theory suggests that coefficient of real income (GDP) is expected to have a positive sign $\left(\xi_{1}>0\right.$. According to our theoretical priors, the quantity of imports to a domestic country/region ought to increase as the real income rises and vice versa. So we expect the coefficient of domestic real GDP to be positive. However, if the rise in real income is due to an increase in production of import substitutes goods, imports may decline as income increases in which case $\left(\xi_{1}<0\right.$. The average unit value of import and domestic prices of COMESA is expected to have a negative sign. The coefficient of foreign reserves is also expected to be positive, because as the foreign exchange constraint is relaxed, imports in a larger quantity are expected to flow into each country and hence the region as a whole.

This study used two separate price terms that is import price $\left(P_{t}^{m}\right)$ and price index of domestically produced goods $\left(P_{t}{ }^{d}\right)$ to capture the price effects on imports instead of relative price ratio formulation. We followed the idea of Murray and Ginman (1976) who argued that relative price specification in the traditional import demand model is inappropriate for estimating aggregate import demand parameter. They suggested a simple modification of the traditional import demand equation that estimates the imports and import competing prices separately. In 
addition, Urbain (1993) suggested that the use of two separate price terms were preferable to the use of one term. He stated that modeling the dynamics of import demand by using relative prices implies identical dynamic response of imports to changes in import prices and domestic prices.

A number of studies have identified real foreign exchange reserves as an additional variable affecting import demand (see Moran, 1989; Faini et al., 1992; Dutta and Ahmed, 1999; and Arize et al., 2004). Omission of foreign exchange reserves may bias a model's empirical estimates and overstates the influence of the included explanatory variables.

To carry out Johansen and Juselius multivariate cointegration approach (1990) and error correction mechanism on import demand Equation (1), it is necessary that all data series must have same integrating order and their linear combinations must be stationary. If the series do not follow the same order of integration, then there can be no meaningful relationship among them. If series are integrated of the same order, we can proceed to the cointegration test. A test for cointegration analysis means looking for stable long-run equilibrium relationships among non-stationary economic variables. If the results indicate that the absence of cointegrating vectors between the variables, it means that there does not exist a long-run stable relationship between them. If cointegration exists, then it can be presumed that a one -way or two-way Granger causality exists in at least the stationery series. However, the implementation ofthe cointegration method necessities the prior check for non-stationarity of data using Augmented-Dickey Fuller (ADF) and Phillips-Parren (PP) tests. This is supported by the recent studies that indicated that testing for unit root is necessary to avoid the problem of spurious results (Shrestha and Chowdhury, 2005; and Jalil et al, 2008).It further helps determine whether the variables are integrated of order $0,1,2$ or beyond. If variables are found to be nonstationary at levels and they are determined to be stationary in their first differences, they are said to be integrated of order one, I(1).Although, this also results in removing out the long run characteristics of the macro economic data, thereby making the model capable or explaining only short run effect.

In each time series, we examined the time series properties of the macro variables using Dickey Fuller (DF), Augmented Dickey Fuller (ADF) and Phillips Perron (PP) unit root tests. The DF, ADF and PP tests (with intercept, with trend and intercept and without trend and intercept) were conducted on both in levels and firstdifferences for all the five variables. This study used the critical values of the nonstandard dickey-fuller unit root distribution for testing $\phi=1$ rather than the standard normal distribution ( $t-$ test $)$.In AugmentedDickey Fuller test, we used the Schwarz Information Criterion, Akaike Information Criterion and Hannan-Quinn Criterion for the selection of optimal lag length. But in Phillips-Parren weused the Bartlett Kernel, Parzer Kernel and Quadratic Spectral Kernel in special estimation method and for optimum bandwidth; we used the NeweyWest Bandwidth and Andrews Bandwidth. In order to examine whether model (1) is spurious or there is a long run equilibrium relationship, the stationarity of the residuals obtained from the regression in model were tested using DF-ADF, PP and DF-GLS unit root tests.

Before undertaking the JJ cointegration test, the relevant order of lags $(p)$ of the Vector Autoregressive (VAR) model has to be 
specified. This is because the results of Johansen Juselius procedure are sensitive to lag length for VAR model and the orders of the integration of the variables entering each of the VAR model. Thus pre-estimation lagorder statistics using VAR diagnostics and tests were employed.Consequent upon this, an appropriate lag-length using the following criteria; Final Prediction Error (FPE); Akaike's Information Criterion (AIC), Schwarz's Bayesian information criterion(SBIC), Hannan and Quinn information criterion (HQIC) and the sequential modified LR test statistic were employed.

With relevant order of lags $(p)$ for the this model, the results of cointegration LR test based on trace and maximal eigenvalue of the stochastic matrix applied to the aggregate import function will be determined. JJ method suggested two statistics that determine the number of cointegrating vectors:trace statistics and maximal Eigen value tests. The concept of cointegration was employed to ascertain whether there is a long-run equilibrium relationship among the five variables of $\ln M_{t}, \ln Y_{t}, \ln P_{t}{ }^{m}, \ln P_{t}^{d}$ and $\ln R_{t}$ of the aggregate import demand model. The appropriate critical values for the tests are provided in Osterwald - Lennum (1992). Thus the null and alternative hypotheses were tested using these tests. Among the five variables under study, there was a possibility of zero, one, or two cointegrating vectors.

The invaluable finding of co-integration analysis is "The Granger Representation theorem," It states that if a set of variables are cointegrated of order one (1), there exists a valid error correction representation of data. If the variables are found to be cointegrated, the 'Granger (1987) representation theorem' should be used to construct an error correction model (ECM). Once the variables included in the VAR model are found co-integrated, the next step is to specify and estimate an error correction model (ECM) including the error correction term to investigate the dynamic behaviour of the model.

The Error term lagged one period (i.e., $E C_{t-1}$ ) integrates short-run dynamics in the long-run aggregate import demand function. This leads us to the specification of a general error correction model (ECM):

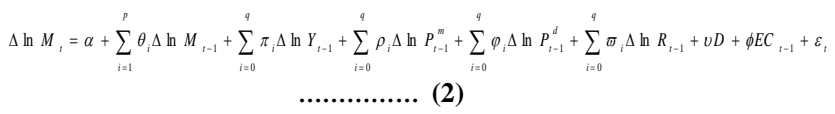

Where:

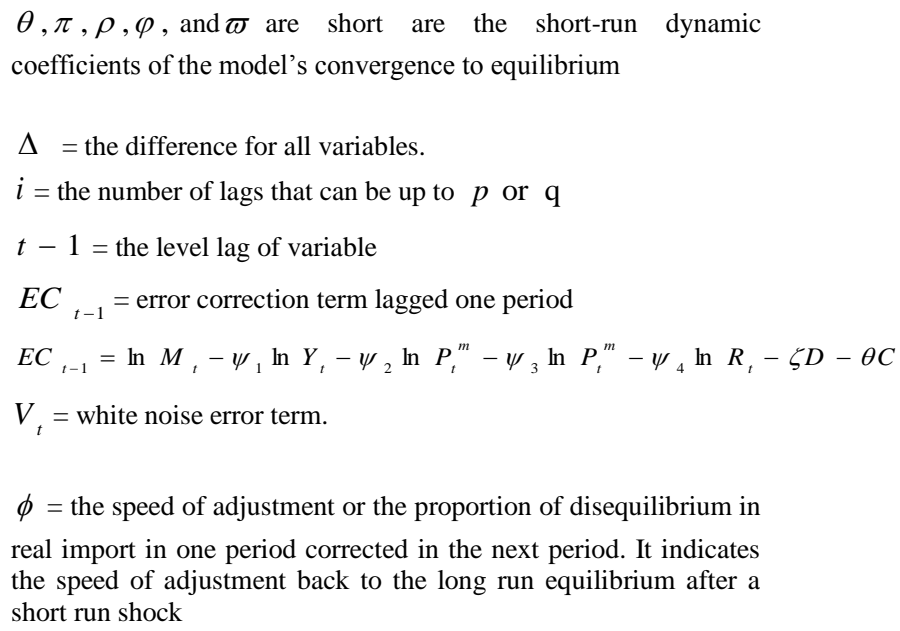
real import in one period corrected in the next period. It indicates the speed of adjustment back to the long run equilibrium after a short run shock

Appropriate procedures for studying the stability over time of regression relationships were employed. Emphasis is placed on the use of graphical methods. Recursive residuals from the aggregate import demand function, defined to be uncorrelated with zero means and constant variance, is used in the analysis. In order to test for long-run parameter stability or constancy suggested by Pesaran and Pesaran (1997), the cumulative sum of recursive residuals (CUSUM) and the cumulative sum of recursive residuals of square 
(CUSUMSQ) tests proposed by Brown et al (1975) to the residuals of the estimated ECMs are employed. In both CUSUM and CUSUMSQ, the related null hypothesis is that all coefficients are stable. The CUSUM test uses the cumulative sum of recursive residuals based on the first observations and is updated recursively and plotted against break point. It is more suitable for detecting systematic changes in the regression coefficients. It is based on the cumulative sum of the recursive residuals and plots the cumulative sum together with the $5 \%$ critical lines over time. CUSUM test finds parameter instability if the cumulative sum goes outside the area between the two critical lines. The CUSUMSQ employs the squared recursive residuals. It is more useful in situations where the departure from the constancy of the regression coefficients is haphazard and sudden.

The data used in this study was sourced from African Development Indicators (2008/2009) which is a publication of World Bank. Africa Development indicators 2008/2009 provided the most detailed collection of data covering 53 African countries with a CD-ROM, covering about 1,400 indicators from 1965 to 2006. Additional data was collected from latest World Bank's World Development Indicators and Global development finance, Statistics from the COMESA secretariat available online, International Financial Statistics (IFS), COMESA Banks Statistical Bulletin and earlier editions of Africa development indicators.

\section{Discussion on Empirical results}

\section{Macroeconomic Time Series Data}

Five annual macroeconomic data are plotted on semi logarithmic graphs for the period under consideration. We use the realization to draw inferences about the underlying stochastic process. Figure 1 is a plot of $\ln M_{t}, \ln Y_{t}$ and $\ln R_{t}$ while figure 2 represents $\ln P_{t}^{m}, \ln P_{t}^{d}$ of the time series in levels. These series seem to be trending upwards, although the trend is not smooth especially in the foreign reserves. The series tend to depict a non-stationary pattern

\section{Unit Roots Tests}

Tables 1 and 2 show summarized results of Mairura Model from of the standard Augmented Dickey-Fuller (ADF) (Said and Dickey 1984), Phillips and Perron (1988) unit root tests respectively where a unit root null hypothesis is tested against a stationary alternative.The results indicate that for all DF-ADF and PP unit root tests, allthe macroeconomic variables are having unit root at level form but not at first difference. This means all series are non-stationary at level but stationary at first difference.95\% critical value for the augmented DickeyFuller statistic (with an intercept but not a trend) and (an intercept and a linear trend) are -2.9499 and -3.5426 respectively.

The results indicate that for all ADF, PP and DF-GLS unit root tests, the residuals of the model (1) were found stationary (Table 3 ). They do not have unit roots. The model is accepted because it is not spurious or nonsense. Thus all the microeconomic variables in the model are cointegrated and have long run equilibrium relationship between them. It is a long run model.

The Johansen and Juselius multivariate trace and maximal eigen value cointegration test (1990) was applied to the variables of model (1).On the basis of SBIC,AIC, HQIC and FBE criteria, a best lag length of one year $(p=1)$ was selected as shown in tables 4. The VAR lag order one year was significant 5\% significance level. 
With relevant order of lags $(p=1)$ for the this model, the results of cointegration LR test based on trace and maximal eigenvalue of the stochastic matrix applied to the aggregate import function are presented in table 5 .

Starting with trace statistics tests for the null hypothesis of no Cointegration $(r=0)$ among the five variables of $\ln M_{t}, \ln Y_{t}, \ln P_{t}{ }^{m}, \ln P_{t}^{d}$ and $\ln R_{t}$ against alternative one cointegrating vector $(r \geq 1)$, the null hypothesis is rejected. Next, the null hypothesis of $(r \leq 1)$ against the alternative cointegrating vector $(r \geq 2)$ is accepted at a standard significance level. In table 4 , trace statistics indicates the presence of one cointegrating vector at 90 and $95 \%$ critical value. The maximum eigenvalues tests are similar to trace statistics results. In the $\lambda$ - max statistics results, null hypothesis of $r=0 \quad$ (no cointegration), is rejected in favour of the alternative hypothesis of $r=1$. Next, the null hypothesis of $r \leq 1$ cannot be rejected in favour of $r=2$. In other words, there is one cointegrating vector $(r=1)$ at 5 and $10 \%$ significant level.

Thus the results from both trace and eigenvalue tests provide strong evidence in favour of a unique long-run equilibrium relationship among the macroeconomic variables of the COMESA aggregate import demand model. Therefore, we can conclude that although the individual data series are non-stationary but their linear combination is stationary, the level estimates are appropriate for policy implications.

It can further be inferred that, the long-run relationship presented in the model is stable. This means that these variables cannot move "too far" away from each other in the longrun and therefore the behaviour of aggregate import demand function was stable during 1970 to 2006.
This cointegrating vector is reported in table 6 that also presents coefficient estimates normalized on aggregate imports.Based on these results, the estimate of the cointegrating vector that represents the longrun relationships between variables identified in the model is given as follows:

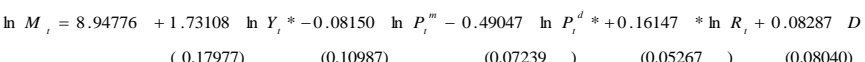

The results suggest that GDP, price of domestically produced goods and Foreign exchange reserves as explanatory variables are significant at $1 \%$ level and therefore have an important role to play in influencing aggregate imports in COMESA. Buoyant domestic activity would likely increase the quantity of imports demanded. The positive coefficient on GDP variable shows the response of imports to a change in income, or alternatively, the marginal propensity to import, which measures the fraction of an extra dollar of income earned that is spent on imports. This shows the extent to which increases in disposable income will reflect in a deterioration inthe trade balance, via increases in imports, rather than in higher domestic absorption. Similarly increased foreign reserves will increase aggregate imports. Adequate foreign reserves pay for import needs. An increase price of domestically produced goods would be expected to lead to a decline in the quantity of imports demanded since its coefficient is negative.

\section{Error Correction Mechanism ( $\left.E C M_{t-1}\right)$}

Since the model 1 is cointegrated, we estimated the error correction model (ECM).Table 7 shows the estimated coefficient of the error correction $E C M_{t-1}$ of $-0.66(0.18107)$ and t-value of -3.6248 is found to be statistically significant at the $1 \%$ level with the expected negative sign. 
Int.J.Curr.Res.Aca.Rev.2016; 4(5): 66-83

Figure 1: In $M_{t}, \ln Y_{t}$ and $\ln R_{t}$, COMESA, 1970-2006 (annually).

InMt, In Yt, InRt for COMESA, 1970-2006

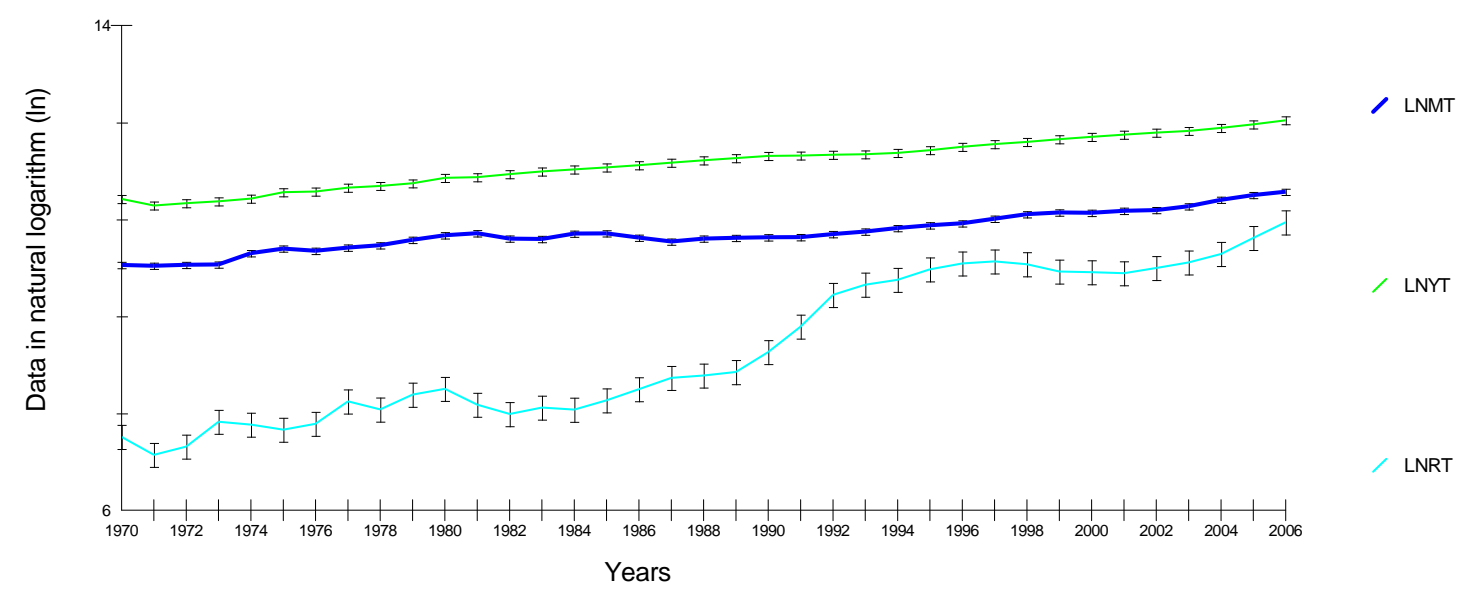

Figure 2: In $P_{t}^{m}$ and $\ln P_{t}^{d}$ COMESA, 1970-2006 (annually).

InPMt. In PDt for COMESA, 1970-2006

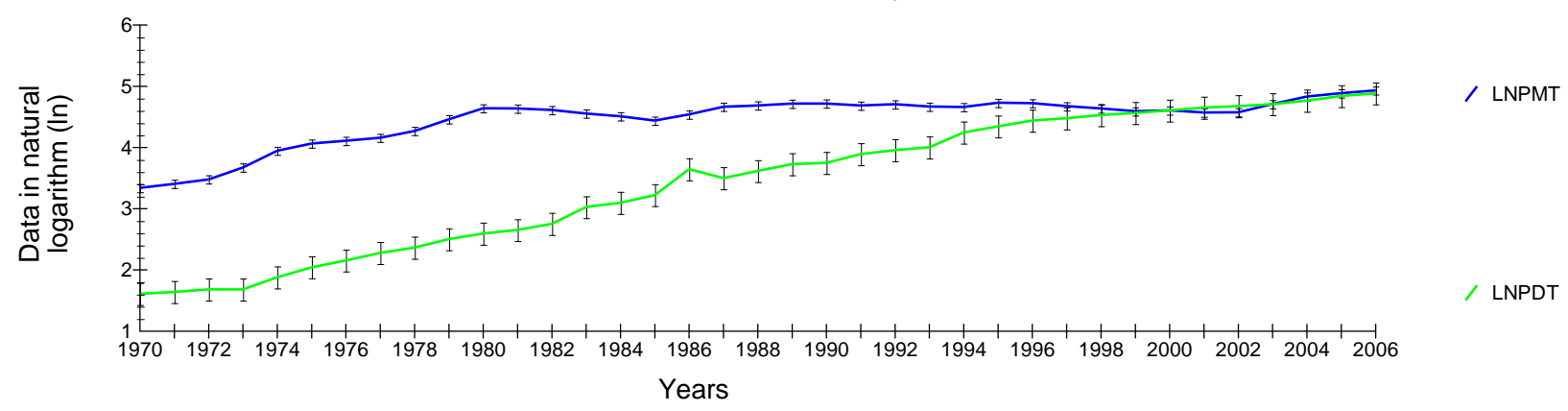

Figure 3: Plot of Cumulative Sum of Recursive Residuals (CUSUM)

Plot of Cumulative Sum of Recursive Residuals

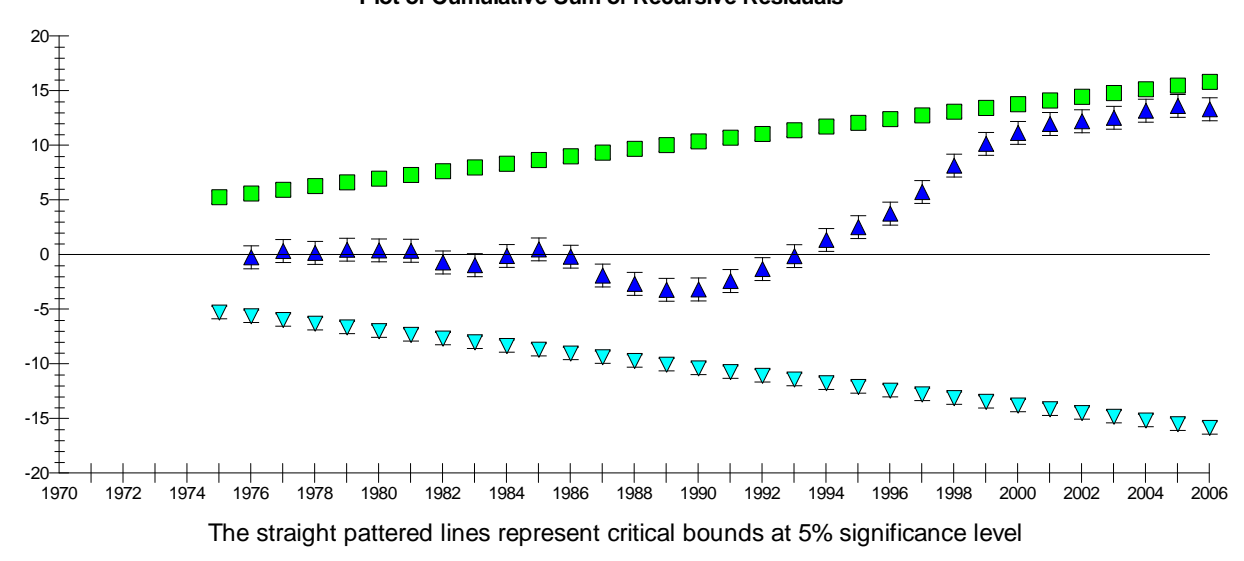


Figure.4 Plot of Sum of squares of Recursive Residuals (CUSUMSQ)

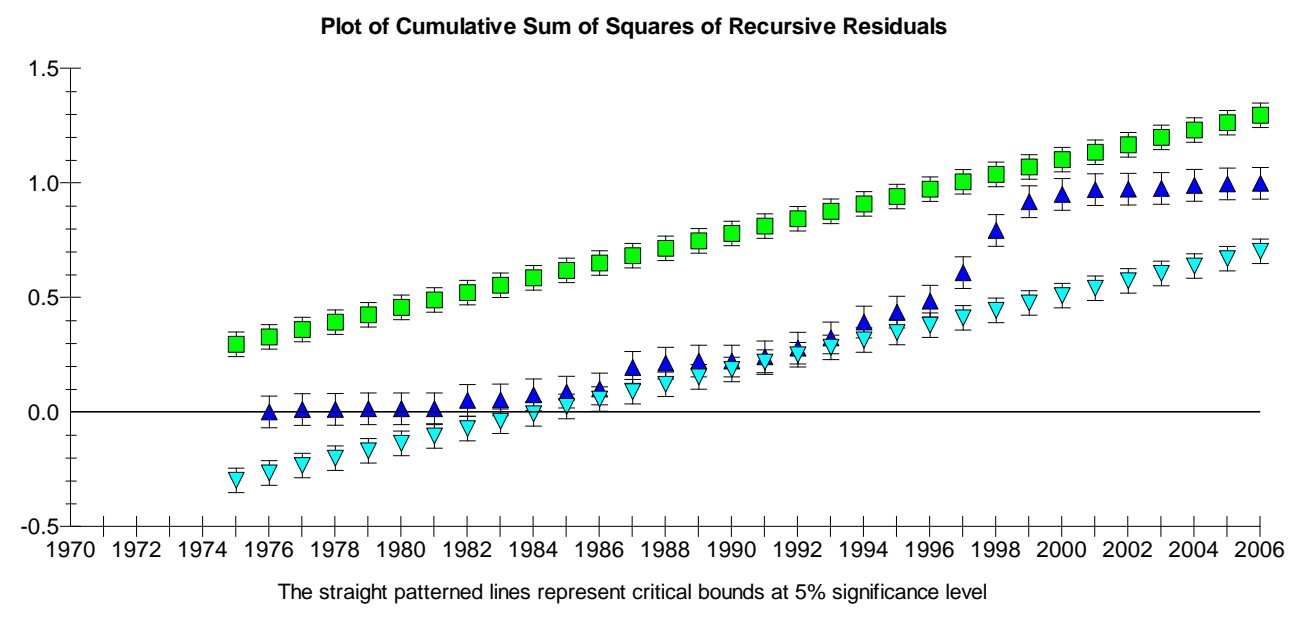

Figure.5 Recursive coefficients test of aggregate import demand model

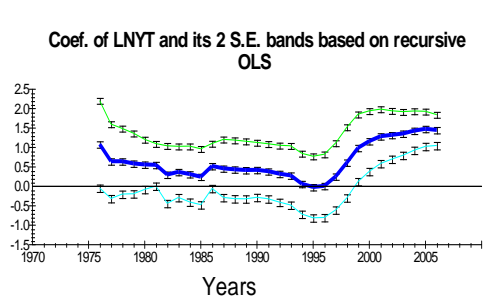

Coef. of LNPDT and its 2 S.E. bands based on recursive OLS

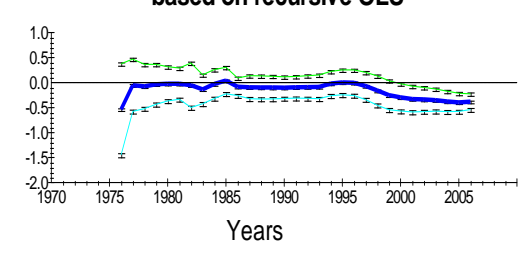

Coef. of LNPMT and its 2 S.E. bands based on recursive OLS

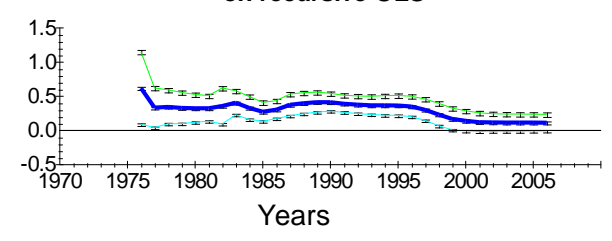

Coef. of LNRT and its 2 S.E. bands based on recursive OLS

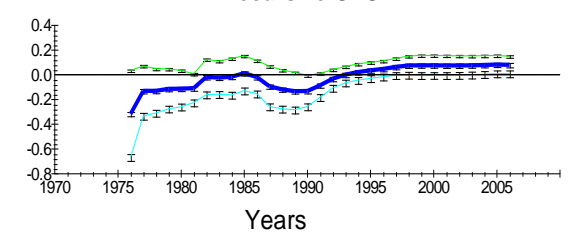

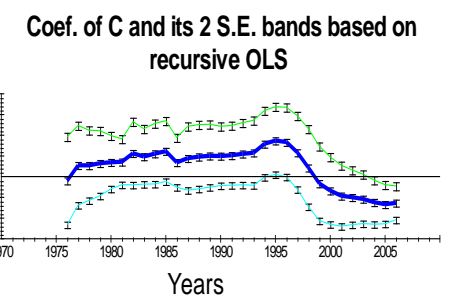


Int.J.Curr.Res.Aca.Rev.2016; 4(5): 66-83

Table.1 DF and ADF Unit Root Test for Stationarity

\begin{tabular}{|c|c|c|c|c|c|c|}
\hline \multirow[b]{2}{*}{ Variables } & \multirow[b]{2}{*}{$\begin{array}{l}\text { Level/first } \\
\text { difference }\end{array}$} & \multicolumn{2}{|l|}{$\mathrm{DF}$} & \multicolumn{2}{|l|}{$\mathrm{ADF}(1)$} & \multirow[t]{2}{*}{ Inference } \\
\hline & & $\begin{array}{l}\text { with } \\
\text { Intercept but } \\
\text { Without } \\
\text { Trend }\end{array}$ & $\begin{array}{l}\text { With } \\
\text { Intercept } \\
\text { and Linear } \\
\text { Trend }\end{array}$ & $\begin{array}{l}\text { with } \\
\text { Intercept but } \\
\text { Without } \\
\text { Trend }\end{array}$ & $\begin{array}{l}\text { With } \\
\text { Intercept } \\
\text { and Linear } \\
\text { Trend }\end{array}$ & \\
\hline \multirow[t]{2}{*}{$\ln M_{t}$} & level & 0.12324 & -1.1404 & -0.20059 & -1.8143 & $\mathrm{I}(1)$ \\
\hline & First Diff. & -4.4537 & -4.4041 & -4.8215 & -4.7830 & $\mathrm{I}(0)$ \\
\hline \multirow{2}{*}{$\ln Y_{t}$} & level & -0.54086 & -1.8871 & -0.51436 & -1.9460 & $\mathrm{I}(1)$ \\
\hline & First Diff. & -5.9038 & -5.8377 & -4.3467 & -4.3236 & $\mathrm{I}(0)$ \\
\hline \multirow[t]{2}{*}{$\ln P_{t}^{m}$} & level & -4.1638 & -3.1995 & -3.1261 & -3.2851 & $\mathrm{I}(1)$ \\
\hline & First Diff. & -2.8135 & -3.0264 & -3.3811 & -3.8487 & $\mathrm{I}(0)$ \\
\hline \multirow{2}{*}{$\ln P_{t}^{d}$} & level & -1.5861 & -0.87234 & -1.7775 & -0.29748 & $\mathrm{I}(1)$ \\
\hline & First Diff. & -7.0637 & -7.7311 & -4.6121 & -5.3763 & $\mathrm{I}(0)$ \\
\hline \multirow[t]{2}{*}{ ln $R_{t}$} & level & -0.10575 & -1.4575 & -0.41973 & -1.9579 & $\mathrm{I}(1)$ \\
\hline & First Diff. & -4.0040 & -3.9557 & -3.8350 & -3.8055 & $\mathrm{I}(0)$ \\
\hline
\end{tabular}

Table.2 Phillips-Perron Unit Root Test for Stationarity

\begin{tabular}{|c|c|c|c|c|c|c|}
\hline Variables & $\begin{array}{l}\text { Level/first } \\
\text { difference }\end{array}$ & Intercept & p-value & $\begin{array}{l}\text { Intercept with } \\
\text { trend }\end{array}$ & p-value & Inference \\
\hline \multirow[t]{2}{*}{$\ln M_{t}$} & level & 0.361 & 0.9800 & -1.270 & 0.8951 & $\mathrm{I}(1)$ \\
\hline & First Diff. & -4.380 & $0.0003^{*}$ & -4.367 & $0.0025^{*}$ & $\mathrm{I}(0)$ \\
\hline \multirow{2}{*}{$\ln Y_{t}$} & level & 0.748 & 0.9908 & -3.335 & $0.0606 * *$ & $\mathrm{I}(1)$ \\
\hline & First Diff. & -5.113 & $0.0000^{*}$ & -5.224 & $0.0001 *$ & $\mathrm{I}(0)$ \\
\hline \multirow[t]{2}{*}{$\ln P_{t}^{m}$} & level & -3.345 & $0.0130^{*}$ & -2.534 & 0.3111 & $\mathrm{I}(1)$ \\
\hline & First Diff. & -2.992 & $0.0357 * *$ & -3.290 & $0.0680 * *$ & $\mathrm{I}(0)$ \\
\hline \multirow{2}{*}{$\ln P_{t}^{d}$} & level & -1.471 & 0.5477 & -0.709 & 0.9725 & $\mathrm{I}(1)$ \\
\hline & First Diff. & -2.992 & $0.0357 * *$ & -3.290 & $0.0680 * *$ & $\mathrm{I}(0)$ \\
\hline \multirow[t]{2}{*}{$\ln R_{t}$} & level & 0.145 & 0.9690 & -2.123 & 0.5331 & $\mathrm{I}(1)$ \\
\hline & First Diff. & -4.176 & $0.0007^{*}$ & -4.218 & $0.0042^{*}$ & $\mathrm{I}(0)$ \\
\hline \multicolumn{7}{|c|}{ gnificance at $1 \%$ and $5 \%$ respectively. } \\
\hline \multicolumn{7}{|c|}{$\begin{array}{l}\text { Notes: } \\
\text { Null hypothesis: The variable has a unit root. } \\
\text { The critical values of PP tests with intercepts and with trend and intercept at } 1 \% 5 \% \text { and } 10 \% \text { levels of } \\
\text { significance are: }-3.675,-2.969,-2.617 \text {, and }-4.279,-3.556,-3.214 \text { respectively. This are Mackinnon critical } \\
\text { values for rejection of hypothesis of a unit root } \mathrm{k}=1\end{array}$} \\
\hline
\end{tabular}


Int.J.Curr.Res.Aca.Rev.2016; 4(5): 66-83

Table.3 OLS Residual Stationarity Test on Error Term (at level)

\begin{tabular}{|l|l|l|l|l|l|}
\hline & Test Statistic & $\begin{array}{l}1 \% \text { critical } \\
\text { value }\end{array}$ & $\begin{array}{l}5 \% \text { critical } \\
\text { value }\end{array}$ & $\begin{array}{l}10 \text { critical } \\
\text { value }\end{array}$ & Inference \\
\hline ADF & -3.081 & -2.644 & -1.950 & -1.604 & $\mathrm{I}(0)$ \\
\hline PP & -4.324 & -2.642 & -1.950 & -1.604 & $\mathrm{I}(0)$ \\
\hline DF-GLS mu & -3.283 & -2.641 & -2.363 & -2.057 & $\mathrm{I}(0)$ \\
\hline
\end{tabular}

Table.4 VAR Lag Order Selection Criteria

\begin{tabular}{l} 
Sample: 1972 -2006; Number of observations $=35$ \\
\begin{tabular}{|l|l|l|l|l|l|l|l|l|}
\hline Lag & LL & LR & df & Prob & FPE & AIC & HQIC & SBIC \\
\hline 0 & 47.6299 & & & & 0.005444 & -2.37885 & -2.28681 & -2.11222 \\
\hline 1 & 61.2501 & $27.241 * *$ & 1 & 0.000 & $0.002652^{* *}$ & $-3.10001 * *$ & $-2.99263 * *$ & $-2.78894 * *$ \\
\hline 2 & 61.9947 & 1.4891 & 1 & 0.222 & 0.002698 & -3.08541 & -2.96269 & -2.72991 \\
\hline
\end{tabular} \\
Regressand: $\ln M_{t}$. Regressors: $\ln Y_{t}, \ln P_{t}{ }^{m}, \ln P_{t}{ }^{d}, \ln R_{t}, D$ and C. \\
Indicates lag order selected by the criterion at $5 \%$ significance level. \\
\hline
\end{tabular}

Table.5 JJ Multivariate Cointegration tests for Real Quantity of Imports and its major determinants

\begin{tabular}{|c|c|c|c|c|c|}
\hline \multirow{2}{*}{$\begin{array}{l}\text { Null } \\
\text { Hypothesis }\end{array}$} & \multirow{2}{*}{$\begin{array}{l}\text { Alternative } \\
\text { Hypothesis }\end{array}$} & \multirow{2}{*}{$\begin{array}{l}\text { Eigen values } \\
\text { in } \\
\text { descending } \\
\text { order }\end{array}$} & Statistics & \multirow{2}{*}{$\begin{array}{l}\text { Critical value } \\
95 \%\end{array}$} & \multirow{2}{*}{$\begin{array}{l}\text { Critical value } \\
90 \%\end{array}$} \\
\hline & & & $\begin{array}{l}\text { Trace value (test) } \\
\lambda_{\text {trace }}=-\mathrm{T} \sum \ln \left(1-\hat{\lambda}_{\mathrm{i}}\right)\end{array}$ & & \\
\hline Null & Alternative & $\begin{array}{l}\text { Eigen } \\
\text { values: } \hat{\lambda}\end{array}$ & Statistic & $\begin{array}{l}95 \% \text { Critical } \\
\text { Value }\end{array}$ & $\begin{array}{ll}90 \% & \text { Critical } \\
\text { Value } & \end{array}$ \\
\hline$r=0$ & $r \geq 1$ & 0.70655 & 113.6540 & 95.8700 & 91.4000 \\
\hline $\mathrm{r} \leq 1$ & $\mathrm{r} \geq 2$ & 0.52674 & $69.5165^{*}$ & 70.4900 & 66.2300 \\
\hline $\mathrm{r} \leq 2$ & $r \geq 3$ & 0.44532 & 42.5847 & 48.8800 & 45.7000 \\
\hline$r \leq 3$ & $r \geq 4$ & 0.33381 & 21.3678 & 31.5400 & 28.7800 \\
\hline$r \leq 4$ & $r \geq 5$ & 0.17064 & 6.7455 & 17.8600 & 15.7500 \\
\hline $\mathrm{r} \leq 5$ & $r=6$ & 0.00270 & 0.0097428 & 8.07000 & 6.6500 \\
\hline Null & Alternative & $\begin{array}{l}\text { Eigen } \\
\text { values: } \hat{\lambda}\end{array}$ & $\begin{array}{l}\text { Maximal Eigen value } \\
\text { (test) } \\
\lambda_{\max }=-\operatorname{Tln}\left(1-\hat{\lambda}_{i}\right)\end{array}$ & $\begin{array}{l}\text { Critical value } \\
95 \%\end{array}$ & $\begin{array}{l}\text { Critical value } \\
90 \%\end{array}$ \\
\hline$r=0$ & $r=1$ & 0.70655 & 44.1376 & 39.8300 & 36.8400 \\
\hline $\mathrm{r} \leq 1$ & $r=2$ & 0.52674 & $26.9318 *$ & 33.6400 & 31.0200 \\
\hline $\mathrm{r} \leq 2$ & $r=3$ & 0.44532 & 21.2169 & 27.4200 & 24.9900 \\
\hline$r \leq 3$ & $r=4$ & 0.33381 & 14.6223 & 21.1200 & 19.0200 \\
\hline $\mathrm{r} \leq 4$ & $r=5$ & 0.17064 & 6.7358 & 14.8800 & 12.9800 \\
\hline$r \leq 5$ & $r=6$ & 0.00270 & 0.0097428 & 8.0700 & 6.5000 \\
\hline
\end{tabular}

Notes: $r$ refers to the number of cointegrating vectors. 
Int.J.Curr.Res.Aca.Rev.2016; 4(5): 66-83

Table.6 Estimated Cointegrated vectors in Johansen Estimation (normalized in Brackets) for COMESA region

\begin{tabular}{|l|c|c|c|c|}
\hline Variables & Coef. & Std. Err. & T- Ratio & Prob \\
\hline $\ln M_{t}$ & $-1.7981(-1)$ &. & &. \\
\hline $\ln Y_{t}$ & $3.1127(1.731086)$ & 0.179767 & -9.63 & 0.000 \\
\hline $\ln P_{t}{ }^{m}$ & $-0.14655(-0.081503)$ & 0.054276 & 1.50 & 0.133 \\
\hline $\ln P_{t}{ }^{d}$ & $-0.88191(-0.490465)$ & 0.072394 & 6.77 & 0.000 \\
\hline $\ln R_{t}$ & $0.29035(0.161471)$ & 0.052673 & -3.07 & 0.002 \\
\hline$D$ & $0.14903(-0.082876)$ & 0.080399 & 1.03 & 0.303 \\
\hline$C$ & 8.947762 &. &. &. \\
\hline
\end{tabular}

Note: Cointegration with unrestricted intercepts and no trends in the VAR; 36 observations from 1971 to 2006. Order of VAR = 1 , chosen $r=1$

Table.7 Error Correction Representations for the selected ARDL for Dynamic Import Demand Model of COMESA: Import as Regressand ( $\Delta \ln M_{t}$ )

\begin{tabular}{|c|c|c|c|c|}
\hline Regressor & Coefficient & Standard Error & T-Ratio & T-Prob. \\
\hline$\Delta \ln M_{t-1}$ & $0.33317^{*}$ & 0.12332 & 2.7017 & 0.015 \\
\hline$\Delta \ln M_{t-2}$ & $-0.40381 *$ & 0.13244 & -3.049 & 0.007 \\
\hline$\Delta \ln Y_{t}$ & $0.92849 * *$ & 0.38166 & 2.4328 & 0.026 \\
\hline$\Delta \ln Y_{t-1}$ & $1.6804^{*}$ & 0.41467 & 4.0523 & 0.001 \\
\hline$\Delta \ln Y_{t-2}$ & $1.5647^{*}$ & 0.41603 & 3.7611 & 0.000 \\
\hline$\Delta \ln P_{t}^{m}$ & $0.20557 * *$ & 0.10743 & 1.9136 & 0.072 \\
\hline$\Delta \ln P_{t}^{d}$ & 0.010591 & 0.068708 & 0.15414 & 0.879 \\
\hline$\Delta \ln R_{t}$ & 0.035252 & 0.300031 & 1.1739 & 0.256 \\
\hline$\Delta D$ & $0.097103 * *$ & 0.042084 & 2.3074 & 0.033 \\
\hline$\Delta C$ & $-5.7615^{*}$ & 1.299 & -4.4355 & 0.000 \\
\hline$e c m_{t-1}$ & $-0.65635^{*}$ & 0.18107 & -3.6248 & 0.002 \\
\hline Serial correlation & $1.81(0.18)$ & & & \\
\hline Functional Form & $0.27(0.60)$ & & & \\
\hline Normality & $6.30(0.043)$ & & & \\
\hline Heteroscedasticity & $2.67(0.10)$ & & & \\
\hline \multicolumn{5}{|c|}{$e c m=\ln M_{t}-1.65632 \ln Y_{t}-0.27518 \ln P_{t}^{m}+0.58712 \ln P_{t}^{m}-0.053710$} \\
\hline \multicolumn{5}{|c|}{ 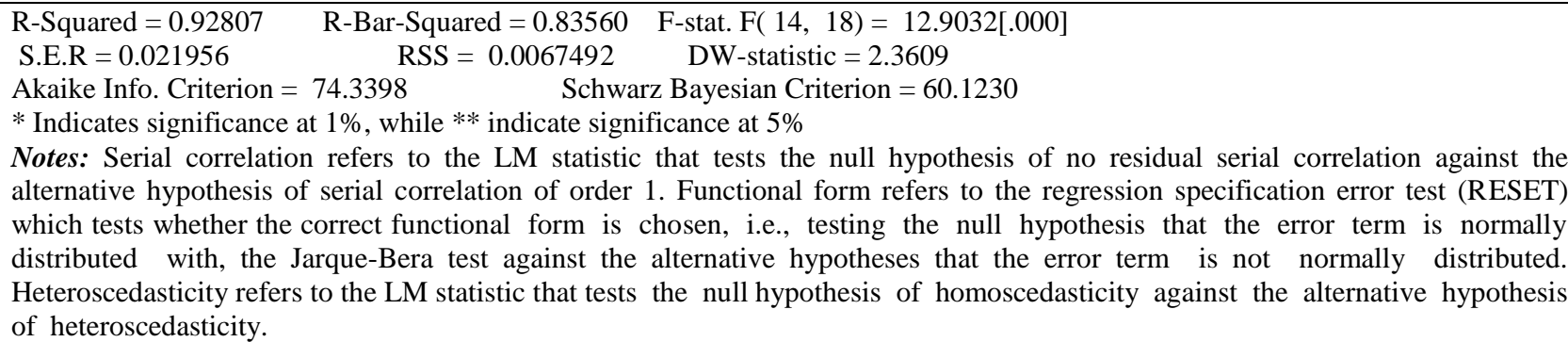 } \\
\hline
\end{tabular}


This suggests the validity of the long run equilibrium relationship among the variables in equation (3.40). Diagnostics test statistics show no evidence of misspecification of functional form, no serial correlation, nor any problem of heteroscedasticity. The adjusted $\left(\overline{R^{2}}\right)$ of 0.83560 explains the strength of the relationship in the model. Moreover $R^{2}<D W$, the model is valid and not a spurious.

The size of the error correction term ( $\left.E C M_{t-1} \mathrm{I}(0)\right)$, which is explanatory power of the ECM model, indicates the speed of adjustment of any equilibrium towards a long-run state. This coefficient suggests that the convergence to long run equilibrium after short run deviation is equal to 0.656 which is a high adjustment process. In other words, the system corrects its previous year period's disequilibrium by $66 \%$ a year.

The coefficients of lag aggregate imports, lag GDP, import prices, structural shifts, price of domestically produced goods and Foreign exchange reserves in the ECM model, show that the mean speed of import adjustments differ depending on whether the adjustment is in response to lag aggregate imports, lag GDP, import prices, structural shifts, price of domestically produced goods and Foreign exchange reserves shocks. Table 7 shows that the mean coefficients of GDP are greater than coefficients of imports and coefficients of imports are greater than the coefficients of structural shifts which are in turn greater than the coefficients of foreign exchange reserves. Similarly the coefficients of foreign exchange reserves are greater than those of price of domestically produced goods. This indicates that there is a faster response of aggregate imports to GDP than import prices, structural shift, foreign exchange reserves and price of domestically produced goods in the short run.

\section{Stability Tests}

The stability of any function is very crucial over the sample period for the efficacy of any policy. The stable import demand function is a symptom of efficient trade policy in any economy. Tests were carried out using CUSUM, CUSUM of squares (Brown, et al., 1975) tests and recursive coefficients test. Figure 3indicate that there is parameter stability over the sample period for the aggregate import demand model because the cumulative sum does not go outside the $5 \%$ two critical lines. Similarly, CUSUMSQ test in figure 4indicates that residual variance is stable over the sample period as cumulative sum of squares remain inside the $5 \%$ critical lines. So, all results provide the evidence of the stability of aggregate import demand function for COMESA. The Recursive Coefficient test in figure shows parameter/coefficient stability for the models as all estimated coefficients are lying within the bands.

\section{Conclusion}

In this paper we empirically re-analyze the aggregate import demand function for COMESA using the Johansen Juselius multivariate cointegration approach and error correction mechanism over the sample period. It presents a theoretically consistent and empirically implementable model of aggregate imports, which has wide applicability given the fact that a large number of developing countries had pursued restrictive and pervasive trade before trade liberalization programme periods. The empirical results further demonstrate the superiority of the model on both statistical and economic grounds. Error correction mechanism used to estimate the long-run as well as the short-run relationships among the variables, show that aggregate 
import demand function is cointegrated with aggregate imports, gross domestic product, unit value of imports, prices of domestically produced goods, foreign exchange reserves and policy structural shift. Thus, there is unique long-run equilibrium relationship for COMESA import demand. The findings suggest the dominance of GDP factor in both the long-run and short-run for determining quantity of import demand. Aggregate import demand is further explained by prices of domestically produced goods but less sensitive to import prices. Foreign exchange reserves were found to have some impact on aggregate imports while the structural policy shift to liberalization was insignificant within the review periods. The Stability Test confirmed that model within the review periods was stable and estimates from this model can be reliably used and provide policy-makers further insight on how to improve the trade balance deficit.

\section{References}

Arize, A., Afifi, R. 1987. An econometric examination of import demand function in thirty developing countries. J. Post Keynesian Economics, Volume 9, pp. 604-616.

Bahmani-Oskooee, M. 1998. "Cointegration Approach to Estimate the Long-Run Trade Elasticities in LDCs," Int. Economic J., 12(3): 89-96.

Box, G.E.P., Cox, D.R. 1964. An Analysis of Transformations, J. Royal Statistical Soc., (Series B), 26, 211-243.

Boylan, T.A., Cuddy, M.P., O' Muireheartaigh, I. 1980. The Functional Form for Aggregate Import Demand Function. J. Int. Eco., Volume 10: 56166.

Brown, R.L., Durbin, J., Evans, J.M. 1975. Techniques for testing the constancy of regression relationships over time. $J$.
Royal Statistical Soc., Volume 37, pp. 149-163.

Carone, G. 1996. "Modeling the US demand for imports through cointegration and error correction", J. Policy Modeling, Vol. 18: 1-48.

Dornbusch, R. 1988. Exchange Rates and Inflation. Cambridge: MIT press.

Doroodian, Khosrow, Rajindar, K., Koshal, Saleh Al-Muhanna. 1994. Anexamination of the traditional aggregate import demand function for Saudi Arabia. Appl. Eco., pp. 909-915.

Dutta, D., Ahmed, N. 1999. An Aggregate Import Demand Function for Bangladesh: A Cointegration Analysis Approach, Appl. Eco., 31: 465-472.

Economic Dynamics and Control. 12: 231 54.

Emran, M.S., Shilpi, F. 1996. "Foreign Exchange Rationing and the Aggregate Import Demand Function." Economics Letters, June, pp.315-322.

Engle, R.F., Granger, C.W.J. 1987. Cointegration and error correction: representation, estimation and testing. Econometrica, 55: 251-76.

Faini, R., Pritchett, L., Clavijo, F. 1992. Import Demand in Developing Countries, in Dagenais, M.G., and P.A. Muet, eds., Int. Trade Modelling, New York: Chapman \& Hall, 279-297.

Gafar, J.S. 1988. "The Determinants of Import Demand in Trinidad and Tobago: 196784," Appl. Eco., 20: 303-313.

Goldstein, M., Khan, M. 1985. "Income and Price Effects in Foreign Trade," in Handbook of Int. Eco., (Eds) Jones, R.W., and P. Kenen, Elsevier, Amsterdam, 1041-1105.

Granger, G.W.J., Newbold, P. 1974. Spurious Regressions in Econometrics" $J$. Econometrics, Volume 2: 111-20.

Hickling, R. 2006. 'Electricity Consumption in the New South Wales: An Application of Cointegration Techniques to Energy Modelling and Forecasting'. Transgrid. Eco. 
Houthakker, H.S., Magee, S.P. 1969. "Income and Price Elasticities in World Trade", Rev. Eco. Stat., Vol.41: 111-25.

Jalil, A., Ma, Y., Naveed, A. 2008. 'The finance-fluctuation nexus: further evidence from Pakistan and China', Int. Res. J. Finance and Eco., Issue 14, pp. 1450-2887.

Johansen, S. 1988. "Statistical Analysis of Cointegrating Vectors.

Juselius. K. 1990. "Maximum Likelihood Estimation and Inference on Cointegration with Applications to the Demand for Money," Oxford Bull. Eco. Stat., 52: 169 - 210.

Juselius, K. 1994. "Identification of the LongRun and the Short-Run Structure: An Application to the ISLM Model," $J$. Econometrics, 63: 7 -36.

Juselius, K. 1992. Testing Structural Hypothesis in a Multivariate Cointegration Analysis of the PPP and the UIP for UK," J. Econometrics, 53: $211-44$.

Khan, M.S. 1974. Import and export demand in developing countries. IMF Staff Papers, 21: 678-693.

Khan, M.S., K.Z. Ross. 1977. The Functional form of the aggregate Demand Equation. J. Int. Eco., Vol. 7: 149-60

Learner, Edward, E., Stern, Robert, S. 1970. Quantitative International Economics, Boston, MA: Allyn and Bacon, inc.

Mairura, C., Anthoney, S.T. 2015. An Econometric Estimation of the Aggregate Import Demand Function for COMESA, Int. J. Curr. Res. Acad. Rev., Volume 3(11): 79-106.
Moran, C. 1989. Imports under a Foreign Exchange Constraint, the World Bank Economic review, Volume 3: 279-95.

Murray, T., Ginman, P.J. 1976. "An Examination of the Traditional Aggregate Import Demand Model", Rev. Econ. Stat., Vol.58: 75-80.

Osterwald-Lenum, M. 1992. 'A Note with Quantiles of the Asymptotic Distribution of the Maximum Likelihood Cointegration Rank Test Statistic. Oxford Bull. Eco. Stat., Vol. 54, pp. 461-472.

Phillips, P., Perron, P. 1988. Testing for a Unit root in time series Regression. Biometrika, Volume 75: 335-46

Raijal, A., R.K. Koshal, C. Jung. 2000. "Determinants of Nepalese Imports," $J$. Asian Eco., 11: 347-354.

Said, E.S., Dickey, D.A. 1984. Biometrika, 71, Volume 3, 599-607.

Sarmad, K. 1988. The Functional Form of the Aggregate Demand Function Equation: Evidence from Developing Countries, The Pakistan Development Review, Volume 28: 309- 15.

Shilpi, F.J. 1990. Estimating Income and Price Elasticities of Imports and Exports of Bangladesh, Research Report No. 122, BIDS. DHAKA, Bangladesh.

Shrestha, M.B., Chowdhury, K. 2005. ARDL Modelling Approach to Testing the Financial Liberalisation Hypothesis. Economics Working Paper Series 2005, University of Wollongong.

Sinha, D. 1997. Determinants of import demand in Thailand, Int. Eco. J., Volume 11, Number 4, pp. 73-83.

\section{How to cite this article:}

Clive Mairura, Mark Korir and T. Anthoney Swamy. 2016. A Reexamination of COMESA's Aggregate Import Demand Function: Multivariate Cointegration Approach. Int.J.Curr.Res.Aca.Rev.4(5): 66-83. doi: http://dx.doi.org/10.20546/ijcrar.2016.405.008 